\title{
Creating space: Sack gardening as a livelihood strategy in the Kibera slums of Nairobi, Kenya
}

\author{
Courtney M. Gallaher ${ }^{\text {* }}$ * \\ Northern Illinois University \\ Antoinette M. G. A. WinklerPrins b \\ Johns Hopkins University \\ Mary Njenga ${ }^{c}$ \\ University of Nairobi and World Agroforestry Centre (ICRAF) \\ Nancy K. Karanja d \\ University of Nairobi
}

Submitted July 2, 2013 / Revised June 9, August 12, October 3, November 14, and December 16, 2014 /

Accepted December 17, 2014 / Published online February 16, 2015

Citation: Gallaher, C. M., WinklerPrins, A. M. G. A., Njenga, M., \& Karanja, N. K. (2015). Creating space: Sack gardening as a livelihood strategy in the Kibera slums of Nairobi, Kenya. Journal of Agriculture, Food Systems, and Community Development, 5(2), 155-173. http://dx.doi.org/10.5304/jafscd.2015.052.006

Copyright (C) 2015 by New Leaf Associates, Inc.

\begin{abstract}
As many countries in sub-Saharan Africa undergo rapid urbanization, a growing number of people are joining the ranks of the urban poor. Urban agriculture is a livelihood strategy used by the poor

a * Corresponding author: Courtney M. Gallaher, Department of Geography/Women, Gender and Sexuality Studies, Northern Illinois University; DeKalb, IL 60115 USA; +1-815-753-6836; cgallaher@,niu.edu

b Antoinette M. G. A. WinklerPrins, Academic Program Director, Environmental Studies, and Faculty Fellow, Department of Earth and Planetary Sciences, Johns Hopkins University; 3400 North Charles Street; 301 Olin Hall; Baltimore, Maryland 21218 USA; antoinette@jhu.edu

c Mary Njenga, Department of Land Resource Management and Agricultural Technologies, University of Nairobi and World Agroforestry Centre (ICRAF); P.O. Box 1253-00606; Nairobi, Kenya; M.Njenga@,cgiar.org
\end{abstract}

to improve their well-being, but it has remained largely inaccessible to inhabitants of slums, who generally lack access to land to farm. However, in the Kibera slums of Nairobi, Kenya, a relatively new form of urban agriculture has emerged, called

\footnotetext{
d Nancy K. Karanja, Department of Land Resource Management and Agricultural Technologies, University of Nairobi; P.O. Box 30197-00100; Nairobi, Kenya; Nancy.Karanja@,cgiar.org
}

\section{Author note}

This research was conducted using support from National Science Foundation (NFS) award BCS-1030325 as well as the Society of Women Geographers Pruitt Dissertation Research Fellowship. The writing of this manuscript was supported by the National Science Foundation (USA) while the second author worked at the foundation. Any opinion, finding, conclusions, or recommendation expressed in this material are those of the author and do not necessarily reflect the views of the National Science Foundation (USA). 
sack gardening, in which farmers plant crops into the sides and tops of large sacks of soil. Our research asked how participation in sack gardening served to improve the livelihoods of farmers in the Kibera slums of Nairobi. We demonstrate that urban agriculture can be a viable and important livelihood strategy for households, even in densely populated slum environments. Low-space urban agricultural activities like sack gardening should receive greater consideration as part of urban development initiatives.

\section{Keywords}

Africa, Kenya, Kibera, livelihoods, sack gardening, urban agriculture

\section{Introduction}

In 2007, the world population hit a landmark with more than $50 \%$ of people now residing in urban areas. While sub-Saharan Africa remains predominantly rural, most countries are projected to be more than $50 \%$ urban by the year 2030 (UNHabitat, 2004). Because most cities are unable to keep up with the need for infrastructure and formal employment, urbanization often leads to the growth of informal settlements, the informal jobs sector, and a growing number of urban poor. Current estimates suggest that nearly 1 billion people worldwide reside in informal settlements or slums, without adequate access to food, shelter, water and sanitation (UN-Habitat, 2010).

Cities are centers of political, social, and economic opportunity in most countries, but they are also home to growing numbers of poor people. ${ }^{1}$ If countries are to address rapid urbanization and the growth of urban poverty, they need to support and empower livelihood strategies that the urban poor have developed to survive. Urban agriculture is one livelihood strategy used by the urban poor to improve their well-being, in combination with other livelihood strategies. Numerous studies of urban and peri-urban agriculture worldwide have demonstrated that it is effective at improving household food security (Binns \& Lynch, 1998; Crush, Hovorka, \& Tevera, 2011; Egziabher, Lee-

1 "Urban poor" refers to the proportion of the urban population living below the poverty line (Wratten, 1995).
Smith, Maxwell, Memon, Mougeot, \& Sawio, 1994; Maxwell, 1995; Mwangi, 1995) and as an incomegenerating activity (Baumgartner \& Belevi, 2001; Drakakis-Smith, Bowyer-Bower, \& Tevera, 1995; Mlozi, 1996). In sub-Saharan Africa, studies of urban agriculture have been limited, but those that have been done generally suggest that approximately one-third of households are engaged in some form of urban agriculture, and that twothirds of the farmers are women (Prain, Karanja, \& Lee-Smith, 2010). While urban agriculture is a fairly common urban livelihood strategy, it has remained largely inaccessible to inhabitants of slums who generally lack access to any open space to farm.

\section{Sack Gardening in Kibera}

In the Kibera slums of Nairobi, Kenya, a relatively new form of agriculture has emerged, called sack gardening. Farmers plant crops into the sides and tops of large sacks of soil, allowing them to grow 20 to 40 plants in the space previously occupied by just a few plants by making use of the vertical space created by the sack. While sack gardening (sometimes called sack farming or vertical gardening) is not new to Kibera, it has become more popular since 2008. Following postelection violence in early 2008 that strongly affected residents of Kibera, a French nongovernmental organization (NGO) called Solidarités began providing free seedlings and technical advice to new farmers as part of an effort to improve household food security. Solidarités' sack gardening program officially ended in 2012, but the practice had been widely adopted and sack gardens can still be seen throughout Kibera today. At the time of our research study, several thousand households in Kibera practiced some form of sack gardening (Karanja \& Njenga, 2011). This form of urban agriculture is practiced on a smaller scale than urban agriculture is typically practiced in other urban and peri-urban parts of Nairobi due to the unavailability of land in the slum. Although sack gardening specifically in the Kibera slums has received a great deal of media attention (e.g., Chesterton, 2011; Doiron, 2011; Karanja and Njenga, 2011), this type of urban agriculture can also be found in most cities in Kenya and other countries around the world (e.g. Hossain, 2013). 
Our research specifically asked how participation in sack gardening has been integrated into the livelihood strategies of farmers in the Kibera slums of Nairobi. We demonstrate that urban agriculture can be a viable and important livelihood strategy for households, even in slum environments. In particular, sack gardens are important to women in Kibera as they fit well with their current livelihood strategies and allow them to provide for their households while building a greater sense of community among the farmers. Through this case study of sack gardening in the Kibera slums, we hope to demonstrate the importance of this form of small-scale urban agriculture, which provides another viable livelihood strategy to the urban poor in in other regions of the world, and even in highly space-constrained urban environments.

\section{Sustainable Livelihoods Approach}

To evaluate the impact of sack gardening on household livelihood strategies, we adapted the sustainable livelihoods approach to examine the ways in which farmers drew on different capitals to support their well-being and ability to farm in the slums. The term "livelihoods" refers to the capabilities, assets, and activities required for a means of living (Chambers \& Conway, 1992). A sustainable livelihoods approach considers different assets used by urban farmers to modify their livelihood strategies and to help them overcome food insecurity. Carney (1998) suggests that a sustainable livelihoods framework is a tool that can help identify the main factors affecting livelihoods and the relationships between them. This framework places poor households at the center of the development process and starts with their capabilities and assets, rather than just their problems (Scoones, 1998). While the urban poor may not have cash savings, they often have access to other assets, such as their labor, health, knowledge, skills, friends, and family, and the natural resources around them, which combined constitute a stock of capitals (Narayan \& Pritchett, 1999). People's livelihoods are dependent on their access to different types of capital, including financial, natural, human, physical, and social. The combination of these capitals or assets constitutes a livelihood strategy, and households strive to use their assets in combination to cope with economic, environmental, health, and political changes (Scoones, 1998).

Residents of Kibera face a range of challenges, including high levels of food insecurity and poverty, frequent threats of violence, and inadequate access to basic goods and services, including sanitation services, health care, and education. Households must creatively use their assets in order to pursue different livelihood strategies in this context. Sack gardening provides a new way for households to draw on their portfolio of capital assets and modify their livelihood strategies as a means of improving their food security or generating income.

Natural capital consists of the natural resources useful to livelihoods, including land, soil, water, and other environmental resources. This form of capital is generally considered to be less significant in cities, but in the context of urban agriculture, natural capital is critical as land is at a premium (Rakodi, 2002). The livelihoods of those practicing urban agriculture are particularly dependent on their access to land, soil, and water.

Physical capital is the basic infrastructure for transportation, shelter, water, energy, and communications, as well as the equipment that enables people to pursue their livelihoods (Rakodi, 2002). The ability of residents to obtain the physical capital required for sack gardening, such as sacks, seeds, and fertilizer, may influence their participation. Additionally, lack of physical infrastructure in Kibera, such as piped water, impedes residents' ability to participate in gardening, as they must use the informal sector to obtain water from streams or wells, or have enough financial capital to purchase water from the water vendors who possess the physical capital to transport it (Villavicencio, 2009).

Human capital refers to the quantity and quality of labor resources, education, skills, and health status of household members (Rakodi, 2002). The ability of households to engage in economic activities is often constrained by the educational levels or health status of household members. Lack of education or skills forces household members to rely on informal labor markets or to participate in activities such as urban agriculture to supplement their incomes (Foeken, 2006). Although sack 
gardening does not require formal education, it does require a particular set of knowledge and skills. Households with recent ties to rural agricultural areas may have more human capital in this area than households whose members have lived for multiple generations in the slums (Linares, 1996; WinklerPrins \& de Souza, 2005).

Financial capital is defined as the financial resources available to people, including savings, credit, pensions, and remittances, which provide them with different livelihood options. In the context of urban agriculture, financial capital refers to the financial resources available to begin sack gardening, such as money needed to purchases water, sacks, and potentially seeds and soil (Rakodi, 2002). Financial capital is strongly dependent on relationships of trust, and is closely related to the next type of capital, social capital (Prain et al., 2010).

Social capital encompasses the social resources, including networks, membership in formal groups, relationships of trust and reciprocity, and access to wider institutions of society, on which people rely when pursuing their livelihoods (Rakodi, 2002). Sack gardening takes place in a densely populated, urban environment. Residents may draw on their social networks for help in building sacks, maintaining the gardens, sharing harvested goods, and protecting sacks against theft, among other activities.

Households practicing urban agriculture make use of these different forms of capital assets in the broader context of policies, institutions, and processes that are applied to and exist in the Kibera slums and the city of Nairobi. They also draw on their assets in response to vulnerability that results from engaging with urban ecosystems (Prain et al., 2010). Our research looked at the ways in which farmers in the Kibera slums made use of these different capital assets to examine how sack gardening has been integrated into household livelihood strategies, and the extent to which this has proven beneficial for the households involved in this type of farming.

\section{Study Area}

The Kibera slum was selected as our research site because it is the largest informal settlement in Nairobi, and it represents some of the most chal- lenging issues faced by residents in informal settlements in Kenya today. Residents of Kibera have participated in sack gardening for several years, with many beginning to garden after the postelection violence of early 2008. At the time of our study, sack gardening was practiced by upwards of 5,000 households (Karanja \& Njenga, 2011). The great diversity of the Kibera slum allows comparisons to be made concerning the impact of sack gardening on livelihood strategies among a wide variety of household structures, income levels, and ethnic backgrounds.

Kibera is located about $7 \mathrm{~km}$ (4 miles) southwest of downtown Nairobi, within the legal city limits (Figure 1). It is East Africa's largest slum, with approximately half a million residents occupying about 2.5 square kilometers (1 square mile), making it one of the most densely populated urban settlements in the world. It consists of 10 villages or neighborhoods, defined loosely along ethnic lines. The villages included in our study were Makina, Mashimoni, Laini Saba, Kianda, Kisumu Ndogo, Soweto East, Soweto West, Gatwekera, and Silanga. The population of Kibera is composed of residents with many different ethnic groups and social backgrounds. Over half of the households live below the poverty line (Sampson, Raudenbush, \& Earls, 1997), but in reality the number of households experiencing poverty is much higher. The income level on which poverty lines are set in Kenya often ignores the cost of nonfood essentials in urban areas, such as the cost of water, health care, and education (Putnam, 2001).

\section{Data Collection}

We conducted our research on the impacts of sack gardening on livelihood strategies over a period of seven months in late 2010 and early 2011 in collaboration with researchers from the University of Nairobi. We used a two-part mixed-methods approach to collect data on the impact of sack gardening on residents' livelihoods, combining qualitative, semistructured interviews with farmers ${ }^{2}$

\footnotetext{
${ }^{2}$ For this study, farmers were defined as those households practicing sack gardening, and nonfarmers were households who did not practice any form of agriculture. The terminology "farmers" and "nonfarmers" is a direct translation from
} 


\section{Figure 1. Map of the Kibera Slums in Nairobi, Kenya}

Approximately 500,000 people reside in this slum, where thousands of households are now involved in sack gardening. The Kibera slum is divided into its own neighborhoods. Our research was carried out in the villages of Makina, Mashimoni, Laini Saba, Kianda, Kisumu Ndogo, Soweto East, Soweto West, Gatwekera, and Silanga.

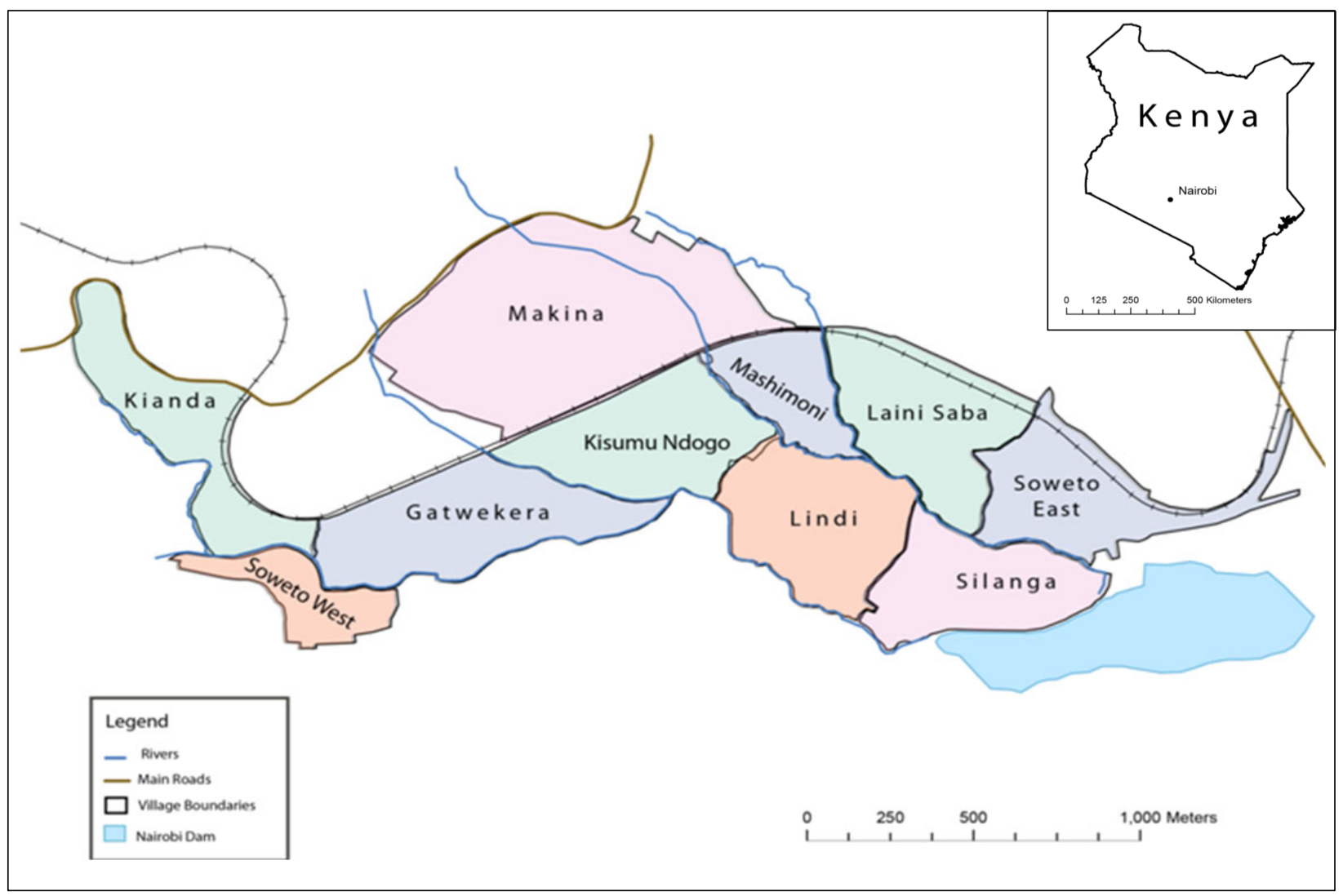

Map created by the first author.

and a quantitative household survey of farmers and nonfarmers. We first conducted qualitative, semistructured interviews with 31 farmers from Makina and Mashimoni villages. Farmers were chosen for the qualitative interviews using purposeful sampling in order to capture a wide variety of factors, including the number of sacks farmed, as well as the age, gender, educational attainment, and length of time farming households were involved in sack gardening. Interviews took place at the farmers' houses and were conducted in Kiswahili by the first author and a research assistant. Farmers were

Kiswahili of how practitioners of sack gardening in Kibera refer to themselves. While they would be considered gardeners by most Western definitions, the use of the term farmer best represents the voice of the people of Kibera. informed about the purpose of the research project and permission was obtained to conduct and make an audio recording of the interview. ${ }^{3}$ During the interview, farmers were asked a range of questions about their experiences with sack gardening in order to understand how they had begun sack gardening, the types of crops they grew, the benefits and challenges of gardening, and any concerns they had about environmental risk.

In the second phase of the study, we used information from initial interviews to craft and then conduct a survey of 306 households in nine villages in Kibera $(n=153$ farmers and $n=153$

\footnotetext{
${ }^{3}$ Human subject clearance for this research was obtained from Michigan State University's IRB, protocol number 10-568; r036781.
} 
nonfarmers). Surveys were pretested on 10 households by field assistants and the first author prior to implementing the full survey. The survey questionnaire asked more specific and quantifiable questions about the how sack gardening was being used as a livelihood strategy, including questions related to the various capital assets, including human, financial, natural, physical, and social capital. See Table 1 for demographic of the survey respondents; there were significant differences between the farmers and nonfarmer respondents in age, time in Kibera, and family size. Households were chosen to be asked to complete the survey using a stratified random sample of farming and nonfarming households in nine neighborhoods in Kibera. Sampling frames ${ }^{4}$ of nonfarmers and farmers in each of nine villages in Kibera were created with the help of a local field assistant from each village. The assistants compiled lists of 35 farmers and 35 nonfarmers in each village, and we randomly selected 17 people to interview from each list. The selected interviewees were contacted to confirm that they would be participating in the survey and to inform them of the time and date of the survey interview. Surveys were administered in Kiswahili with the help of four enumerators, all of whom were local university students.

\section{Data Analysis}

Semistructured, qualitative interviews were recorded, transcribed, translated from Kiswahili, and analyzed using thematic analysis (Waitt, 2005) using the software NVivo in order to determine the major themes that participants identified related to sack gardening as a livelihood strategy. Data from the household survey were analyzed using the statistical software package SPSS (Version 15). We used a series of independent t-tests and Pearson's correlations to test the significance of mean values between farmers and nonfarmers at a 95\% confidence level $(p<0.05)$ for differences in the ways in which they engaged with natural, physical, financial, social, and human capital to use sack gardening as a livelihood strategy.

\footnotetext{
4 Sampling frame is a statistical term referring to a list of all individuals in a population that can be sampled.
}

Table 1. Demographic Overview of the Household Survey Participants

\begin{tabular}{lcc}
\hline & Farmers & Nonfarmers \\
\hline Sample Size & 153 & 153 \\
\hline Age (years) & $34.4^{*}$ & $29.5^{*}$ \\
\hline Time in Kibera (years) & $14.8^{*}$ & $11.6^{*}$ \\
\hline Family Size & $5.2^{*}$ & $4.2^{*}$ \\
\hline
\end{tabular}

Level of Education

Upper Primary Upper Primary

* Indicates a statistically significant difference between farmers and nonfarmers $(p<0.05)$.

\section{Sack Gardening as a Sustainable Livelihood Strategy}

Sack gardening is a livelihood strategy now pursued by thousands of households in the Kibera slums of Nairobi (Karanja \& Njenga, 2011). As discussed earlier, it is advantageous because it allows households to plant a large number of crops in a relatively small space by taking advantage of the vertical growth of plants. The majority of farmers we surveyed grew a combination of four crops in their sack gardens: kale (Brassica oleracea); Swiss chard (Beta vulgaris), known locally as "spinach"; green onions (Allium wakige); and coriander (Coriandrum sativum). A small number of farmers also reported planting varieties of squashes or pumpkins, harvested for the leaves, (Cucurbita spp.), tomatoes (Solanum lycopersicum), "managu" (Solanum scabrum), "nderema" (Basella alba), and "murenda" (Corchorus spp.). The last three are African indigenous vegetables. Farmers who grew kale, Swiss chard, green onions, or coriander all consumed the crops they grew. A smaller number also sold or shared the crops (primarily kale and Swiss chard). Of the farmers who sold their crops, about $80 \%$ sold the crops informally to friends and family, with the remainder selling to vegetable vendors or at their own vegetable stalls.

Sack farmers in Kibera had an average of five sack gardens, although this varied by village within Kibera. Because open land is extremely scarce in Kibera, farmers with larger numbers of sacks tended to situate them on public or unclaimed land, rather than land owned by members of the household or the landlord. Many of these sack 
gardens were located in close proximity to a pit latrine, an open sewage drain, under a clothesline, or next to a road. Farmers frequently fenced off their sack gardens using plastic sacks, strings, or wires in order to protect them from theft by passers by, from livestock such as chickens, and from trash that is swept into the garden area. Based on our household survey, farmers in Kibera had been planting sacks for an average of 1.6 years (19 months), ranging from 2.1 years in Silanga village, where it was first introduced, to 1 year in Makina and Kianda.

Farmers' livelihoods are dependent on their access to different types of capital, including financial, natural, human, physical, and social, thus examining the ways in which farmers' draw on these capitals or assets illustrates how sack gardening has been adopted as a livelihood strategy in Kibera.

\section{Natural Capital}

Access to natural capital, including soil, water, and access to land, was very challenging for many farmers in Kibera. While it did not deter them from planting sack gardens, they were often forced to plant fewer sacks than desired or to forgo caring for their sack gardens because they could not get enough water to irrigate them.

Soil: Farmers obtained their soil from a variety of sources, including open fields near their house, old construction sites, the railroad that passes through the slums, old dumpsites, the riverbank, and various other locations. The village where the farmers lived was roughly correlated with the source of their soil, with farmers from Mashimoni, Kisumu Ndogo, and Soweto West being more likely to take soil from the nearby railroad or dumpsites, while farmers from Soweto East, Gatwekera, Laini Saba, Makina, and Silanga tended to dig soil from open fields near their house. Only farmers from Gatwekera collected soil from the riverbank, as this village is located closest to the Nairobi River, which passes along the southern boundary of the Kibera slums. Our broader study found that farmers who collected soil from dumpsites were more likely to have high levels of heavy metal contamination $(\mathrm{As}, \mathrm{Cd}$, and $\mathrm{Pb}$ ) in the soils and in their crops (Gallaher, Mwaniki, Njenga, Karanja, \& WinklerPrins, 2013).

Nearly all the farmers collected their soil for free, but about $5 \%$ of farmers paid to have someone to transport it to their houses. These farmers paid an average of 50 shillings (US\$0.63) for labor to fill a sack with soil, with the cost ranging from 25 to 200 shillings per sack (US $\$ 0.32$ to US $\$ 2.52$ ). Only about a third of farmers reported asking permission to collect soil from a location; the others did not ask.

Collecting soil was a challenge for many farmers because soil is heavy, there are limited collection sites given the high density of the housing in the slums, and it is difficult to obtain permission to collect the soil from public land. During the qualitative interviews many farmers expressed concerns about being caught while collecting soil from the railroad, as this is an illegal activity. One farmer explained,

We usually get the soil from near the railroad. It's not easy to go and dig the soil because it's an offense if you are caught. We go to the railroad in the evenings, as if we are stealing, because if you go during the day and you are caught, you will be sent to jail.

Not surprisingly, most of the farmers we surveyed who collected soil from the railroad reported that they did not ask permission. A few people responded that they had gotten permission from a local official, but it is possible that these farmers reported getting permission because they felt uncomfortable admitting to an illegal activity.

Water: Obtaining water to irrigate their sacks was another major challenge faced by farmers in Kibera. The slum lacks major water distribution outlets, resulting in frequent and acute water shortages throughout the slums. This has led to an informal water system whereby people access water though small, individually owned pipes that are illegally connected to small water mains that serve nearby residential areas. These pipes crisscross Kibera, passing through sewage-filled drainage ditches or through people's homes. Water vendors who have pipes with large water storage tanks con- 
nected to these informal systems supply more than $85 \%$ of residents (Schippers, 2000). Findings from our interviews indicate that during water shortages, the amount of time it takes to collect water also increases as many pipes run dry, and women often must spend several hours collecting water during these times. As a result of the increased cost and effort required to obtain water during frequent water shortages, farmers often refrain from irrigating their sack gardens in order to prioritize domestic water needs. Overall, the cost of water was the most substantial expense associated with sack gardening, and a small number of farmers said that they chose not to maintain their sack gardens during the dry season due to the high cost of water.

Irrigation water for sacks was obtained from a variety of sources, depending on the season (Figure 2). During the wet season, most farmers ( $94 \%)$ relied exclusively on rainwater to irrigate their sacks, while during the dry season farmers were more dependent on water from other sources. More than half of farmers (53\%) we interviewed purchased water from a public tap within Kibera, with the next most common sources of irrigation water being open public wells $(22 \%)$ or taps within a housing compound (18\%).

Few farmers reported using grey water from their homes in order to water their sacks due to concerns about contaminating the food in their gardens with soap residue from washing clothes or doing dishes. Although grey water, particularly water from rinsing clothes or dishes, is likely safe to use, their concerns stemmed from the training they received from the NGO Solidarités, which instructed them that soap residues would kill the plants in their sack gardens.

Access to land: During the qualitative interviews, nearly half the farmers we interviewed said that finding adequate space for their sacks was a major challenge (Figure 3). Several farmers said that they would have planted a greater diversity of plants, particularly indigenous vegetables, if they had more room to build more sacks. In addition, a few women said they had taught their friends how to construct a sack garden, but lack of space prevented their friends from actually building them.

The lack of space in Kibera also meant that farmers often were forced to place their sacks in potentially unsanitary locations, including under a clothesline or next to a latrine $(30 \%)$, next to a drainage ditch with raw sewage $(23 \%)$, or next to a road $(25 \%)$ (Figure 4). Lack of space also led to conflicts between farmers and their neighbors. As one farmer explained,

Our plots here in Kibera are very squeezed so sometimes you place your sacks on your neighbor's doorstep. They may not be interested in building their own sacks, but they will pick your vegetables when you are not there. But I don't quarrel with my neighbors because Kibera is very sensitive. Just one little thing can build and explode. 


\section{Figure 3. Finding Adequate Space to Place the Sack Gardens is One of the Major Challenges Faced by Farmers in Kibera}

This row of sacks is shared by four different households and occupies the front yard (alley) shared by these houses.

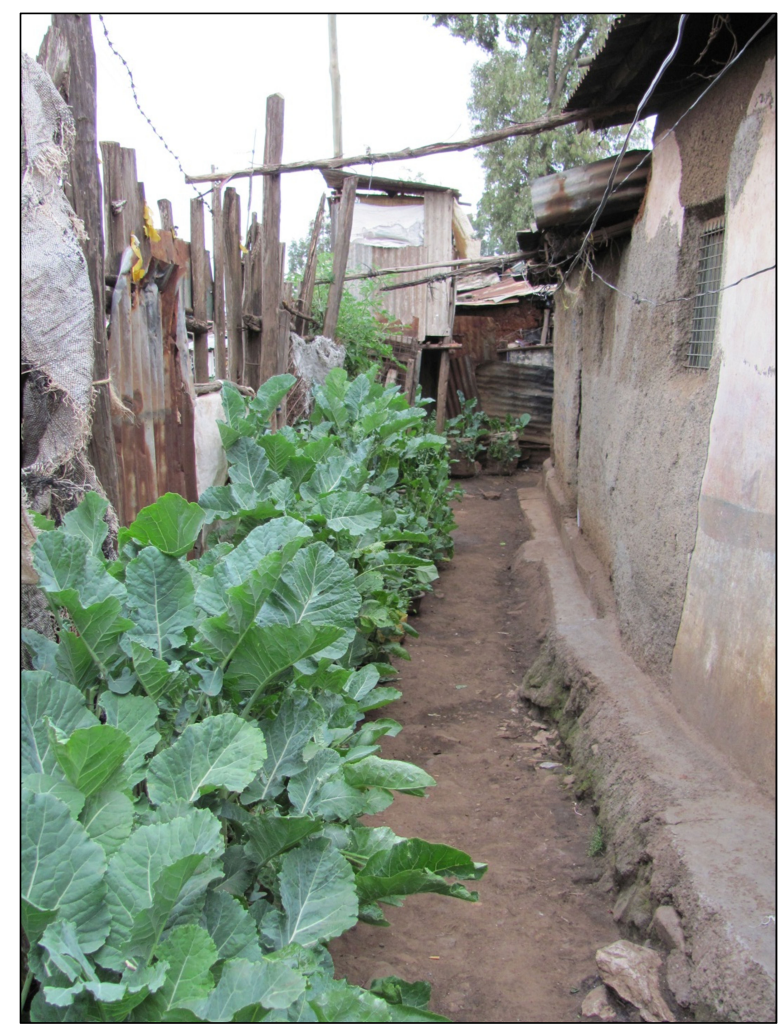

Photo by C. Gallaher, 2010.

\section{Physical Capital}

In contrast to the difficulties reported in obtaining natural capital, farmers generally had an easy time acquiring the physical capital needed to participate in sack gardening in Kibera.

Sacks: Sacks were generally made of a nylon mesh material and were originally used for transporting grains such as rice and maize to shopkeepers. Farmers obtained sacks from multiple sources. About $80 \%$ percent of farmers purchased at least some of their sacks (at an average cost of 20 shillings (US\$0.25) per sack), with the others previously owning or being given their sacks. Sack farmers had an average of 5 sacks in their gardens, although this varied somewhat by village. Farmers in Gatwekera, Laini Saba, Kianda, and Soweto

\section{Figure 4. Because Sacks Were Frequently Placed Near Open Sewage Ditches or Latrines, Flies Were a Common Problem}

Farmers had to carefully wash their crops to remove the fly excrement before eating the vegetables.

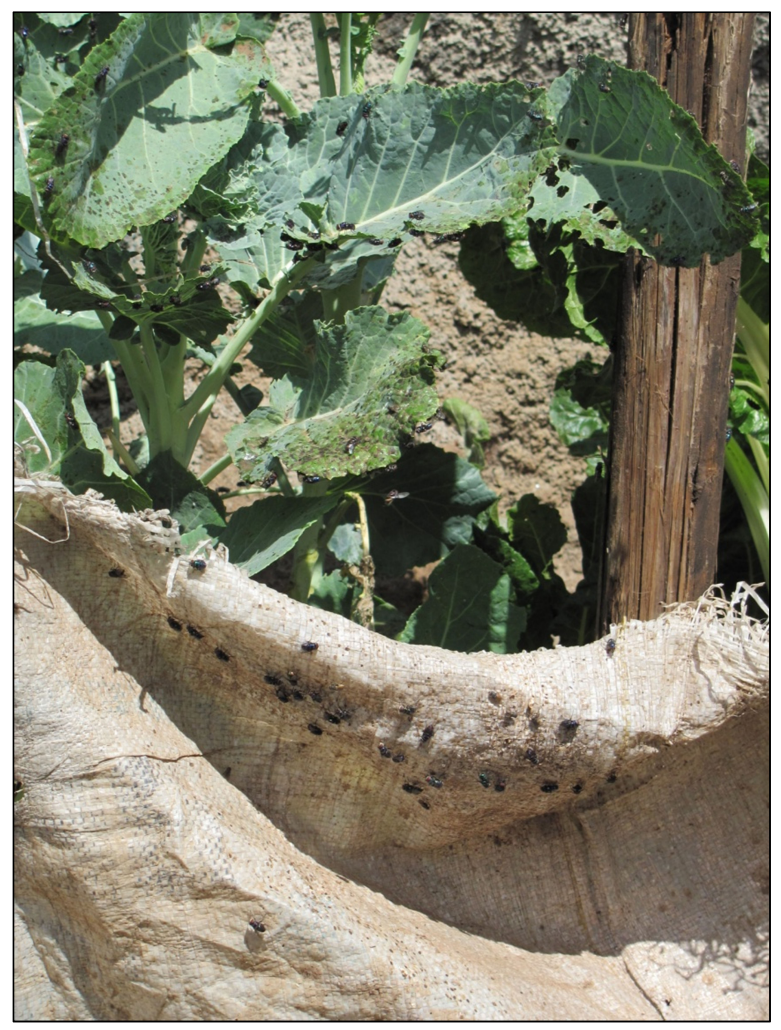

Photo by C. Gallaher, 2010.

West had an average of 6 or 7 sacks per household, while in the other villages within Kibera farmers had only 3 to 5 sacks per household.

Seeds: Nearly all farmers reported obtaining seeds and seedlings for their crops from the local NGO Solidarités that has been active in promoting sack gardening within the Kibera slums. This NGO offered free kale and Swiss chard seedlings and green onion and coriander seed packets to all farmers who registered with their organization. As such, many farmers who were trained by family members later registered with Solidarités in order to obtain the planting material. When Solidarités ran out of seedlings or seed packets, farmers then resorted to purchasing seeds and/or seedlings from local markets. Anecdotal accounts also suggest that farmers have begun to plant suckers (offshoots) 
from other farmers' existing kale plants rather than obtaining new seedlings from the Solidarités nursery. According to the farmers, these suckers are considered to be a healthier variety of kale plants than those available from the nursery, and to be less prone to diseases or insect damage.

Fertilizers: Farmers applied a variety of fertilizers to their sack gardens, including chemical fertilizers, compost, dumpsite waste, plant residue, and manure from cows, goats, chickens, and rabbits (Figure 5). Manure was mixed into the soil at planting, while other forms of fertilizer were applied postplanting. Over one-third of farmers applied manure to their sacks, while only $10 \%$ used chemical fertilizers, and less than $10 \%$ used compost, plant residue, or waste from dumpsites. Manure was typically obtained from friends and family or from Solidarités, or purchased as a group of farmers in order to share the cost. Farmers reported using compost or dumpsite waste when manure was hard to obtain. Chemical fertilizers were purchased by the farmers or given to them by Solidarités. Farmers typically avoided using night soil (human waste) since Solidarités had warned them that this could spread disease.

Pesticides: About $80 \%$ of farmers applied some form of pesticide to their crops, sometimes applying combinations of different types of pesticides. The most commonly applied pesticides include chemical pesticides and ash. Ash was collected from charcoal stoves and sprinkled on leaves as a traditional form of pest control. About $20 \%$ of farmers interviewed had applied a different type of traditional pesticide, which involved mixing hot pepper, soap, and garlic in a water solution and spraying it on the crops. Chemical pesticides were generally given to farmers by Solidarités or purchased as part of a group, where each farmer contributed 20 to 100 shillings (US $\$ 0.25$ to US $\$ 1.26$ ) for a tin of pesticides.

\section{Human Capital}

While sack gardening does not require any formal education, it does require knowledge related to farming and caring for plants. Thus, we hypothesized that households with stronger ties to rural agricultural areas or previous experience with farming would be more likely to be involved in sack gardening.

Previous Experience with Agriculture: The majority of farmers and nonfarmers $85 \%$ and $75 \%$, respectively) have had previous experience with mixed farming in rural areas, mostly before they migrated to Kibera. A smaller number of households (13\% and $7 \%$, respectively) were previously involved in some form of vegetable farming in urban areas. Overall, respondents with previous agricultural experience were more likely to currently practice sack gardening than those without. We would have expected respondents who had more recently moved to Kibera to have stronger ties to rural, agricultural areas. However, we found no significant correlation between their length of residence and previous experience farming, whether urban or rural. Nor were gender or household wealth signifi-

\section{Figure 5. Fertilizer Use Among Farmers}

Many farmers in Kibera use fertilizer in their sack gardens, with animal manure being most commonly used ( $n=153$ ).

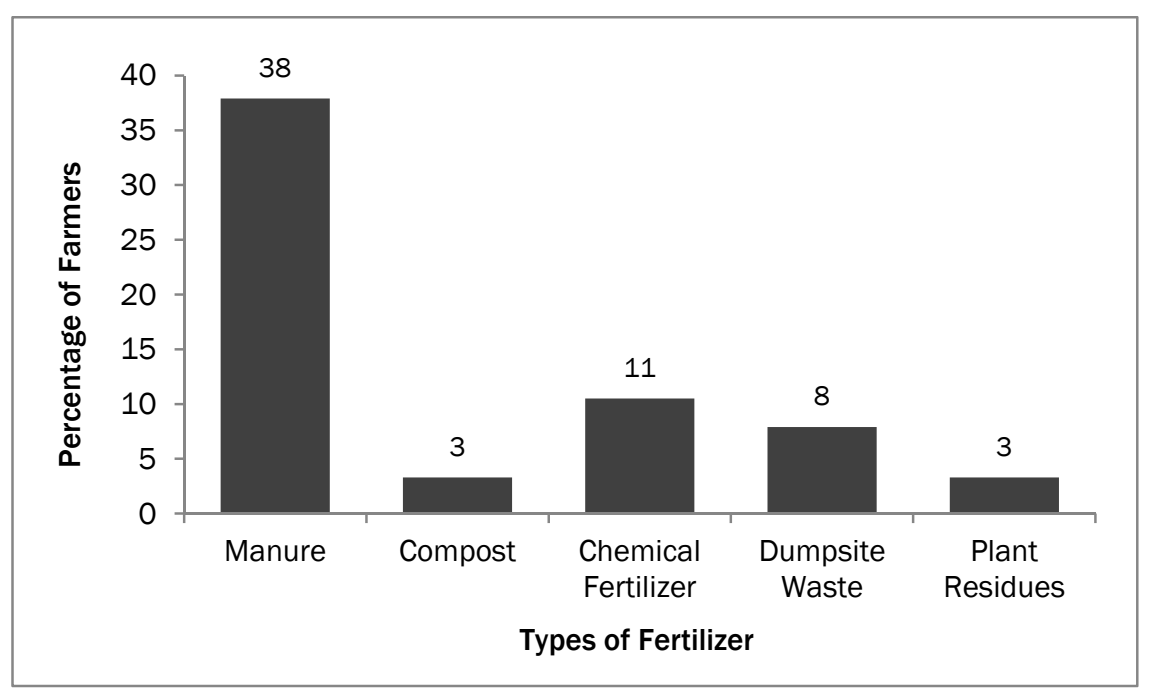


cantly correlated with their length of residence in Kibera. However, older respondents were more likely to have had previous urban farming experience than were younger respondents. In terms of labor for sack gardening, women carried out the majority of farming tasks. Of the men farmers surveyed, nearly all received help from their spouse or children with some farming-related tasks, including building the sacks, planting, weeding, watering, applying fertilizers and pesticides, or harvesting the crops. This is consistent with previous studies that demonstrated that women typically provide the labor for small-scale urban agriculture (Hovorka, 2006a).

Education: There was no significant difference in the average level of formal education between household members of farming and nonfarming households. Beyond formal education, trainings about how to build and farm with sack gardening were important sources of information. Farmers received training about sack gardening from a variety of sources, including Solidarités $(86 \%)$, family and friends (33\%), and other NGOs or church groups $(<5 \%)$, with many farmers trained by more than one source. Nonfarmers had also received training from Solidarités $(12 \%)$ or family and friends in Kibera (8\%), but had chosen not to adopt sack gardening for various reasons, such as lack of interest, time, and/or resources. About $87 \%$ of farmers reported teaching someone else about some aspect of sack gardening. The importance of these types of farmer training in urban agriculture has been documented among urban farmers in other parts of Kenya (Lee-Smith, 2010).

Building Human Capital: An interesting issue that was raised repeatedly during the qualitative interviews was the extent to which sack gardening had contributed to the creation of human capital among farmers. Farmers we interviewed reported sharing knowledge about sack gardening with their friends and family in Kibera or other parts of Kenya, or even teaching children and relatives how to plant and maintain sack gardens. One farmer we spoke with explained that she had been frustrated when she saw her neighbor's young children pick- ing leaves from her kale plants. But then she realized the children had been collecting small piles of soil and were pretending to plant her kale leaves into their "garden." Through their play, these children were showing an interest in farming, so she was no longer upset they were harvesting her kale.

With their newfound knowledge about sack gardening, farmers reported feeling proud or more confident as a result. They felt healthier, happier, and more confident because they were better able to provide for their families or share their vegetables with their friends. They also felt that sack gardening had given women more confidence because of the challenges they undergo as part of farming. A similar sense of empowerment through urban gardening has been documented among women farmers in South Africa (Slater, 2001) and Botswana (Hovorka, 2006b).

\section{Financial Capital}

In the context of urban agriculture, financial capital refers to the financial resources available to start gardening, such as money to purchase soil, seeds, water, and tools (Rakodi, 2002). Asking households directly about their income and expenditures is a sensitive subject, and people often have a poor understanding of their household's income and expenditures. Few urban poor have salaried employment, so household incomes fluctuate according to business revenues or the availability of casual labor. Likewise, prices for goods in the slums also fluctuate frequently. Thus, overall measures of household wealth are often approximated based on proxy assets, such as ownership of various household items, land, or housing tenure, as well as expenditures on basic needs like food (Montgomery, Gragnolati, Burke, \& Paredes, 2000). Our survey compared financial capital available to farming and nonfarming households to see what financial assets are available to these households and to see if sack farming had any effect on a variety of measures of household wealth. An internal study completed by Solidarités in 2010 suggested that households needed to have at least three sack gardens in order to have extra produce from their gardens to sell for cash (M. Ng'ang'a, personal communication, September 4, 2010). Qualitative interviews with farmers revealed 
that many people were conscious of their monetary savings from sack gardening, and they used money they would have spent on vegetables to purchase other goods. By comparing various measures of financial capital between farming and nonfarming households, we go beyond the cost-benefit analysis completed by Solidarités to examine the impact sack farming has on creation of household wealth.

Housing Tenure: Previous studies have demonstrated a positive relationship between housing tenure and household wealth (e.g., Filmer and Pritchett, 2001), so our study investigated housing tenure as a proxy for household wealth. We found no significant difference between farmers and nonfarmers in terms of housing tenure. The longer a respondent had lived in Kibera, the more likely they were to own their own home $(p \leq 0.00)$. This is because the housing market in Kibera is extremely tight, and most homes are owned by a small number of landlords. Only the families who have lived in Kibera for a long time were able to own homes there because they had original land tenure rights. However, families who rented their homes may have acquired some degree of wealth despite not owning their house or plot of land. The majority of households $(93 \%)$ interviewed during the survey rented their houses.

Household Income:

Household income is another measure of household wealth. Most households reported that they earned 4,000-8,000 shillings (US\$50100) per month, consistent with other studies of household income in Kibera

(DesGroppes \& Taupin, 2011). Reported household incomes ranged from less than 1,500 shillings (US\$18) to more than 20,000 shillings (US\$250) per month. While we saw no significant difference in total household income between farmer and nonfarmer households, the sources of this household income differed (Figure 6). The majority of households interviewed earned income from a small business or as casual laborers, and about $30 \%$ of farming households reported receiving some income from sack gardening. Farmers were significantly more likely than nonfarmers to have a salaried employee contributing income to the household ( $d f=302, p=0.04$ ).

\section{Proxy Assets of Household Wealth}

Household income is often a poor indicator of the long-term financial well-being of a household, especially since income can vary widely among households who depend on casual labor and small business (Filmer \& Pritchett, 2001). Instead, researchers often measure long-term household wealth by looking at proxy assets, such as whether or not a household owns a television, mobile phone, or radio, to assess the long-term financial capital of a household. We asked about ownership of a set of items that have previously been identified as good indicators of household wealth in Kibera (Ngongo et al., 2007). These assets were assigned a weight based on the inverse proportion
Figure 6. Sources of Household Income for Farmers and Nonfarmers in Kibera $(n=305)$

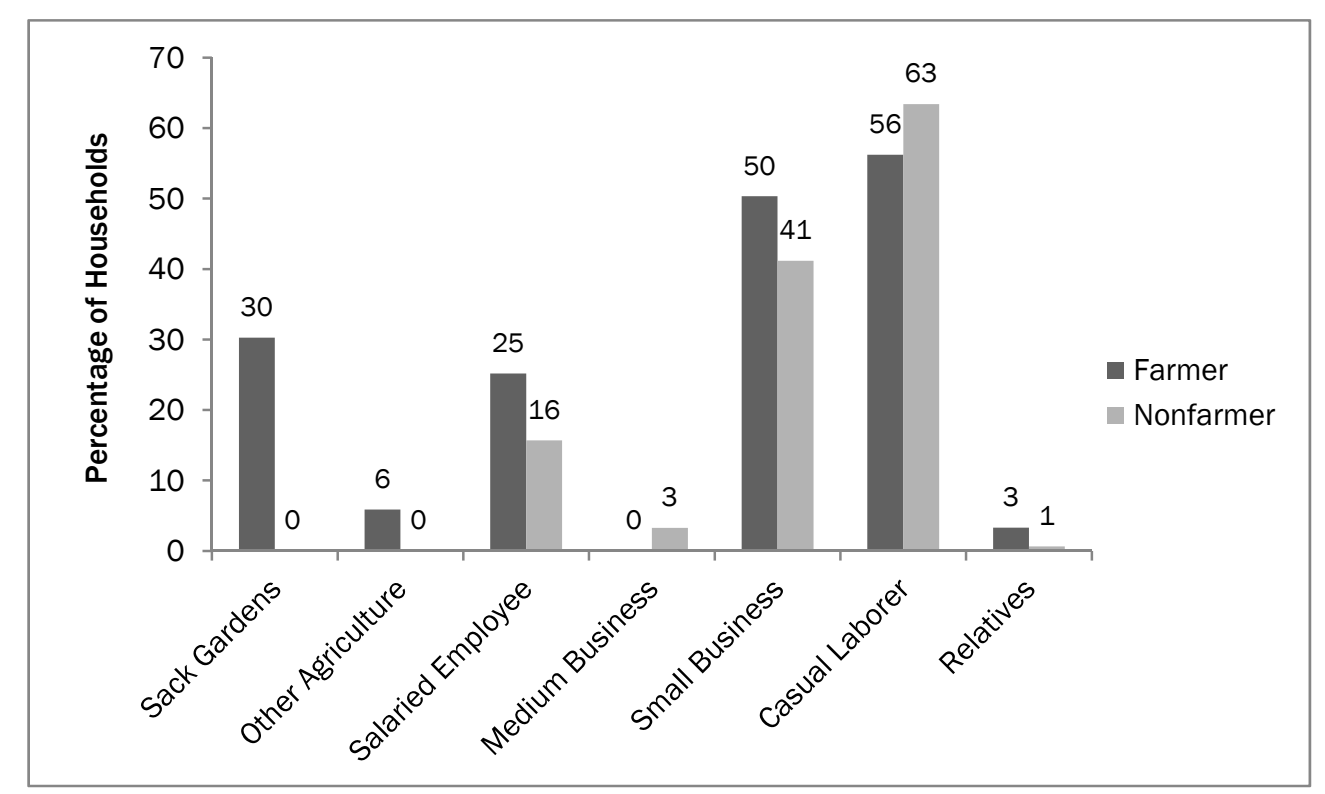


of the number of households that owned the item: items that were more commonly owned were assigned lower weights than those that were owned by a smaller number of households. A household wealth index was then created by totaling the weighted assets owned by each household.

We found no significant difference in household wealth between farmer and nonfarmer households in Kibera. These findings were not surprising given that sack gardening contributes relatively little income to farming households. Additionally, interviews with farmers revealed that they were most likely to spend money earned from selling their vegetables on household expenditures, such as food or cooking charcoal, rather than on durable goods that were counted as part of a household's total assets. While sack gardening may be important financially to a household in terms of supplementing its food supply or providing extra spending money for things like school supplies for children, we were not able to demonstrate any impact on a household's long-term wealth, as measured by its physical assets. It does have significant nonmonetary benefits, including improving household food security and building social capital among community members (Gallaher, Kerr et al., 2013).

Income Spent on Food: The proportion of total income that a household spends on food is another important indicator of a household's financial capital. During our qualitative interviews, many farmers explained they had benefited from sack gardening by being able to obtain food from their gardens, or by selling vegetables from their gardens in order to purchase flour or cooking fat. Our survey found that food is a major expense for most households in Kibera, with farmers and nonfarmers spending $50-75 \%$ of their total income on food. On days that farmers harvested food from their sack gardens, they spent significantly $(d f=149$, $p<0.00$ ) less of their total monthly household income on food compared to days they did not harvest, indicating that farming does provide some financial savings to farming households. Participating in urban agriculture as a means of subsidizing household income is common and widely documented in East Africa (e.g. Foeken 2006), although it had not been documented previously for small-scale agriculture like sack gardening.

Savings: A final important aspect of financial capital is savings. Many of the farmers we talked to viewed sack gardening as a means of saving money in their household budgets. Based on our qualitative interviews, farmers chose to save their money in different ways. Some women set aside the money for an unspecified goal. Others saved the money to buy household items, such as clothing, shoes, or pens for their children, or to pay their rent each month. Several farmers contributed their savings to microfinance organizations, called merry-go-rounds, and borrowed money from the same saving and credit system to invest in household goods. One farmer, Beatrice, ${ }^{5}$ began sack gardening in 2008 and had seven sacks at the time of our interview. In addition to using the vegetables for home consumption, she was able to sell some once a week at the local market. She used the money she saved from not purchasing vegetables, and the extra money she earns from selling them, to buy household items like soap, cooking fat, and flour. Beatrice felt she had benefited from sack gardening so much that she formed a women's group where women shared space for their sack gardens and helped each other with labor such as watering and weeding the gardens. Another farmer we interviewed reinvested the money saved from her sack gardens into her business. By investing her savings of 200 shillings (US\$2.50) in her dried fish business, she was able to generate over 1,000 shillings (US\$12.50) in profit by the end of the month. Participation in informal savings and credit systems is an important form of wealth creation in Kenya, especially for slum dwellers who lack access to traditional financial institutions. Sack gardening has positively affected farmers in Kibera by generating income that has allowed them to participate in savings and credit systems.

\section{Social Capital}

In the densely populated slum environment of Kibera, residents must navigate a complex landscape where people from different regions of

\footnotetext{
5 The names of all study participants have been changed to protect their identity.
} 
Table 2. Correlation Coefficients for Significant $p$-values Reported in the Text Related to Social Capital For all tests, $n=306$ (153 farmers, 153 nonfarmers).

\begin{tabular}{llcc}
\hline Correlated Variables & & $\begin{array}{c}\text { Correlation } \\
\text { coefficient }\end{array}$ & $\begin{array}{c}\text { Significance } \\
(\boldsymbol{p} \text {-value })\end{array}$ \\
\hline Sharing seedlings & Age of farmer & -0.164 & 0.04 \\
\hline Sharing seedlings & Place of birth (proxy for ethnic group) & 0.192 & 0.02 \\
\hline Own land they farm & Willingness to share farming spaces & & $\leq 0.00$ \\
\hline $\begin{array}{l}\text { Number of social groups farmers } \\
\text { participate in }\end{array}$ & Help others with gardening activities & 0.391 & 0.179 \\
\hline Trained by Solidarités & Consult with other farmers about farming issues & 0.04 \\
\hline
\end{tabular}

Kenya, of different ethnicities, and speaking different languages, must co-exist. People's lives are often governed by informal rules and regulations that dictate interactions between different groups of people. Social capital refers to norms and networks that enable people to act collectively, and these norms and networks draw upon notions of trust and reciprocity between individuals or groups of people (Rakodi, 2002). Our research investigated how people used social capital to facilitate sack gardening, as well as whether sack gardening helped to strengthen farmers' social capital.

Group Membership: One measure of social capital is membership or involvement in different types of social groups (Putnam, 2001). Farmers were significantly more likely to participate in a social group, agricultural or not, than were nonfarmers $(d f=304, p \leq 0.00)$. As part of groups of sack gardeners, farmers frequently discussed farming issues, shared the cost of farm inputs, received training together, and planted or harvested together. For example, in Mashimoni village, some of the women farmers we interviewed had formed a gardening group called the Big Five ${ }^{6}$ women's group. This group is composed of several neighbors who share space for their sack gardens and who help with agricultural labor, including carrying the soil for the sacks together, as well as planting, watering, and weeding. They also collaboratively

${ }^{6}$ The name of the women's group is a reference to the Big Five wild animals of East Africa, which are the lion, elephant, Cape buffalo, rhinoceros, and leopard. These animals are known for being the fiercest and rarest of the wild animals in East Africa, and the name of the women's group was likely chosen to reflect this resilience. purchase fertilizer and pesticides for their sacks, with the chairperson of the group purchasing and applying the pesticides to each member's sacks. Other social groups frequently centered around religious activities, contributions to a merry-goround, or other activities such as business training, with the most common group activity being a merry-go-round. Although types of groups that people are involved in globally varies by region, participation in all these types of groups allows members to form new social networks and build the overall social capital of the community. Greater community social capital has been linked to reductions in crime (Akçomak \& ter Weel, 2012), improved health outcomes (Elgar, Davis, Wohl, Trites, Zelenski, \& Martin, 2011), and agricultural innovation (Heemskerk \& Wennink, 2004).

Shared Farming Activities: During our qualitative interviews, farmers reported that they shared their vegetables with their friends and cooperated with other farmers by helping to carry soil for their sacks or sharing seedlings. They also bought water from each other and consulted about different farming issues. Outside of participating in a social group, these activities were important in terms of helping to build friendships or cooperation.

Findings from the larger household survey confirmed many of the observations from the semistructured, qualitative interviews about the ways in which farming activities were shared. Sharing seeds or seedlings with each other was negatively correlated with age, meaning that younger farmers tended to share with each other more than older farmers $(p=0.04$ ) (Table 2), and they also tended to share seeds with people of the 
same ethnic group ( $p=0.02)$. Sharing labor for constructing sacks was marginally negatively correlated $(p=0.06)$ with household income, suggesting that poorer households tend to help each other to construct their sacks while wealthier households may be able to afford to pay someone to help them. Whether farmers owned the land their sacks were placed on strongly predicted whether they shared the space where they placed their sacks $(p<0.00)$. Shared garden spaces were more likely to be on public land, or land owned by another landlord, rather than on land owned by the farmer.

Importantly, farmers with greater social capital, as measured by participation in social groups, were also more likely to help with informal shared farming activities, including sharing seedlings, helping to carry soil, constructing sacks, and sharing space for planting ( $p \leq 0.00)$. This likely reflects their greater connectedness with other members of the community. Finally, farmers were more likely to consult with other farmers about farming-related issues if they first learned about sack gardening from Solidarités $(p=0.04)$. This is likely because this NGO requires farmers to participate in training sessions together to learn how to construct and care for their sack gardens, which seems to facilitate forming social ties between the farmers.

Relationship with their Neighbors: During qualitative interviews with farmers, many reported that sack gardening had strengthened friendships or cooperation between themselves and their neighbors as a result of sharing their vegetables with their friends, sharing extra seedlings, helping each other to carry soil or build their sacks, or pooling money to buy fertilizer and pesticides. Sack gardening has helped to create a sense of community because it has given people reasons to talk to their neighbors. They buy water from each other, consult with each other about problems, and create employment for each other. This study found that sack farming has been a way to bring the women of certain neighborhoods together, and according to one farmer, has decreased tensions between different ethnicities in Kibera. Following the post-election violence of 2008 that took place between different ethnic groups in Kibera and throughout Kenya, it is significant that sack gardening has brought women of different ethnic groups together.

Respondents who were part of the household survey were asked to rate their relationships with their neighbors, from very good (speak every day) to poor (do not get along). Farmers reported having significantly ( $d f=304, p \leq 0.00)$ better relationships with their neighbors than nonfarmers. In addition, almost one-third of farmers (32\%) reported that they now interact with their neighbors more frequently than they did before they began sack gardening. In Kibera, where it is normal for multiple households to share a single housing block, having a good relationship with one's neighbors is important for a household's safety and survival, and is thus and a good measure of a person's social capital.

Exchanges of Goods: Exchanges of goods and services between friends and neighbors in urban areas are another important measure of that household's social capital. Because our research demonstrated that sack gardening had strengthened friendships and improved many farmers' relationships with their neighbors, we expected that farming households might give and receive goods more frequently than nonfarming households. Farmers were significantly more likely than nonfarmers to receive harvested goods (vegetables), labor for agriculture, and information from their neighbors. Those farmers who reported that their relationships with their neighbors had improved since beginning sack gardening were significantly more likely to receive information, labor for agriculture, and cash loans from their neighbors. The greater availability of cash loans was particularly important because this demonstrates that farmers had improved their social safety net as a result of beginning farming.

All the above measures of social capital among farmers and nonfarmers are particularly important because our broader research found that higher social capital was strongly correlated with household food security (Gallaher, Kerr, Njenga, Karanja, \& WinklerPrins, 2013).

\section{Summary and Conclusions}

This research on sack gardening in the Kibera slums of Nairobi demonstrates that sack gardening 
is a viable livelihood strategy that residents of the slum have successfully integrated with other existing urban livelihood strategies. Households drew on their capital assets in a variety of ways as they practiced urban agriculture. Farmers drew on both physical and natural capital to enable them to set up and maintain their sack gardens. Physical capital, such as sacks and seeds, was relatively easy for farmers to obtain. However, insecure access to natural capital, including land, soil, and water, was one of the major limiting factors in determining how many sacks a farmer had, or whether they were able to begin farming. Farming households with greater human capital, mainly those with previous agricultural experience, were more likely to participate in sack gardening. Sack gardening also helped to build human capital by teaching farmers a new skill that they were able to share with others. Sack gardening contributed to financial capital through income generated from sales of vegetables and savings by producing vegetables for the household's own use. This income was saved through local savings and credit systems and also used to meet other household needs, such as paying for health services, rent, and food. Finally, sack gardening positively contributed to farmers' social capital by creating stronger social networks between those involved in gardening groups, creating a greater sense of community, and strengthening friendships between farmers and also between farmers and their nonfarming neighbors. These findings have broader implications for urban agriculture in cities worldwide because they demonstrate that slum dwellers are able to successfully integrate small-scale urban agriculture activities into their urban livelihood strategies. However, farming in informal settlements does have particular challenges. Access to natural capital including soil, irrigation water, and land must be addressed for these small-scale urban agricultural methods to succeed.

In the context of increasing urbanization, development programs need to support a variety of livelihood strategies that are accessible to the urban poor. While urban agriculture is often inaccessible to slum dwellers because they lack access to land, our case study has demonstrated that low-space agriculture is a viable livelihood strategy and there- fore deserves greater attention as part of global urban development initiatives. Sack gardening has spread in popularity and is now being promoted by many community development organizations throughout the world as a way of improving household food security and diversifying local livelihood strategies. Our broader research on sack gardening in Kibera found that it positively influenced household food security (Gallaher, Kerr, et al., 2013) but that there are legitimate concerns about contamination of food grown in sack gardens as a result of the highly contaminated soil in many slum environments (Gallaher, Mwaniki, et al., 2013). Further research is needed in other urban environments to see if sack gardening can be scaled up to promote diversified livelihoods and household food security without compromising the long-term health of the inhabitants.

Additionally, for sack gardening and more generally urban agriculture to be viewed as a permanent and viable, long-term option for urban development and promotion of urban food security, more needs to be done to formally recognize urban agriculture as a legal activity. In many countries in sub-Saharan Africa, urban agriculture is still illegal or lacks official government support. Thus despite the great potential of urban agriculture to contribute to livelihoods of the urban poor, it does not receive the attention it deserves in the context of urban planning, agricultural extension, and overall development initiatives. Formally recognizing urban agriculture as a viable urban livelihood strategy would provide much needed institutional support to urban farmers.

\section{Acknowledgements}

We would like to express our sincere thanks to the households that participated in this research project. We are also immensely grateful to Dennis Mwaniki, Catherine Wangui, George Aloo, Joel Boboti, Baraka Mwau, Jack Odero, and Jamie Clearfield, who contributed to this project in a variety of ways.

\section{References}

Akçomak, İ. S., \& ter Weel, B. (2012). The impact of social capital on crime: Evidence from the Netherlands. Regional Science and Urban Economics, 42(1-2), 323-340. http://dx.doi.org/10.1016/ j.regsciurbeco.2011.09.008 
Baumgartner, B., \& Belevi, H. (2001). A systematic overview of urban agriculture in developing countries. Dübendorf, Switzerland: EAWAG (Swiss Federal Institute for Environmental Science \& Technology) and SANDEC (Dept. of Water \& Sanitation in Developing Countries). Retrieved from http://www.eawag.ch

Binns, T., \& Lynch, K. (1998). Feeding Africa’s growing cities into the 21 st century: The potential of urban agriculture. Journal of International Development, 10(6), 777-793. http://dx.doi.org/10.1002/(SICI)10991328(1998090)10:6\%3C777::AID-JID532\%3E 3.0.CO;2-Z

Carney, D. (Ed.). (1998). Sustainable rural livelihoods: What contribution can we make? London: Department for International Development.

Chambers, R., \& Conway, G. R. (1992). Sustainable rural livelihoods: Practical concepts for the 21st century (IDS

Discussion Paper No. 296). Brighton, UK: Institute of Development Studies. Retrieved from http://www.ids.ac.uk/publication/sustainablerural-livelihoods-practical-concepts-for-the-21stcentury

Chesterton, M. (2011). Sack gardening in Kibera's slums [Radio series episode]. In Earth Beat_-Back to the Land. Radio Netherlands Worldwide. Retrieved from http://www.rnw.nl/english/article/sackgardening-kiberas-slums

Crush, J., Hovorka, A., \& Tevera, D. (2011). Food security in Southern African cities: The place of urban agriculture. Progress in Development Studies, 11(4), 285-305. http://dx.doi.org/10.1177/146499341001100402

Desgroppes, A., \& Taupin, S. (2011). Kibera: The biggest slum in Africa? Les Cahiers de l'Afrique de l'Est, 44, 23-34. Retrieved from Sciences de l'Homme et de la Société (HAL) website: https://halshs.archives-ouvertes.fr/halshs$\underline{00751833}$

Doiron, R. (2011, May 17). For residents of Kibera, good food is in the bag [Web log post]. Kitchen Gardeners International. Retrieved from http://kgi.org/blogs/roger-doiron/residentskibera-good-food-bag

Drakakis-Smith, D., Bowyer-Bower, T., \& Tevera, D. (1995). Urban poverty and urban agriculture: An overview of the linkages in Harare. Habitat International, 19(2), 183-193. http://dx.doi.org/10.1016/0197-3975(94)00065-A
Egziabher, A. G., Lee-Smith, D., Maxwell, D. G., Memon, P. A., Mougeot, L. J. A., \& Sawio, C. J. (Eds.). (1994). Cities feeding people: An examination of urban agriculture in East Africa. Ottowa: International Development Research Centre (IDRC). http://www.idrc.ca/EN/Resources/Publications/ Pages/IDRCBookDetails.aspx?PublicationID =365

Elgar, F. J., Davis, C. G., Wohl, M. J., Trites, S. J., Zelenski, J. M., \& Martin, M. S. (2011). Social capital, health and life satisfaction in 50 countries. Health \& Place, 17(5), 1044-1053. http://dx.doi.org/10.1016/j.healthplace.2011. $\underline{06.010}$

Filmer, D., \& Pritchett, L. H. (2001). Estimating wealth effects without expenditure data_-or tears: An application to educational enrollments in states of India. Demography, 38(1), 115-132. http://www.jstor.org/stable/3088292

Foeken, D. (2006). "To subsidise my income": Urban farming in an East-African town. Leiden, the Netherlands: Brill.

Gallaher, C.M., Kerr, J. M., Njenga, M., Karanja, N. K., \& WinklerPrins, A.M G. A. (2013). Urban agriculture, social capital, and food security in the Kibera slums of Nairobi, Kenya. Agriculture and Human Values, 30(3) 389-404. http://dx.doi.org/10.1007/s10460-013-9425-y

Gallaher, C. M., Mwaniki, D., Njenga, M., Karanja, N. K., \& WinklerPrins, A. M. G. A. (2013). Real or perceived: The environmental health risks of urban sack gardening in Kibera slums of Nairobi, Kenya. EcoHealth, 10(1), 9-20. http://dx.doi.org/10.1007/s10393-013-0827-5

Heemskerk, W., \& Wennink, B. (2004). Building social capital for agricultural innovation: Experiences with farmer groups in sub-Saharan Africa (Bulletin 368). Amsterdam: Royal Tropical Institute (KIT). Retrieved from http://www.kit.nl/sed/wpcontent/uploads/publications/761 Bull368Building-web.pdf

Hovorka, A. J. (2006a). Urban agriculture: Addressing practical and strategic gender needs. Development in Practice, 16(1) 51-61. http://dx.doi.org/10.1080/09614520500450826

Hovorka, A. J. (2006b). The No. 1 Ladies' Poultry Farm: A feminist political ecology of urban agriculture in Botswana. Gender, Place and Culture, 13(3), 207-225. http://dx.doi.org/10.1080/09663690600700956 
Hossain, S. T. (2013, May). Organic sack gardening in Bangladesh. Retrieved from New Agriculturalist website: http://www.new-ag.info/en/research/ innovationItem.php? $\mathrm{a}=2982$

Karanja, N., \& Njenga, M. (2011). Feeding the cities. In L. Starke (Ed.), 2011 State of the world: Innovations that nourish the planet (pp. 109-111). New York: Norton.

Lee-Smith, D. (2010). Cities feeding people: An update on urban agriculture in equatorial Africa. Environment and Urbanization, 22(2), 483-499. http://dx.doi.org/10.1177/0956247810377383

Linares, O. F. (1996). Cultivating biological and cultural diversity: Urban farming in Casamance, Senegal. Africa 66(1), 104-121. http://dx.doi.org/10.2307/1161514

Maxwell, D. G. (1995). Alternative food security strategy: A household analysis of urban agriculture in Kampala. World Development, 23(10), 1669-1681. http://dx.doi.org/10.1016/0305-750X(95)00073-L

Mlozi, M. R. S. (1996). Urban agriculture in Dar es Salaam: Its contribution to solving the economic crisis and the damage it does to the environment. Development Southern Africa, 13(1), 47-65. http://dx.doi.org/10.1080/03768359608439873

Montgomery, M. R., Gragnolati, M., Burke, K. A., \& Paredes, E. (2000). Measuring living standards with proxy variables. Demography, 37(2), 155-174. http://dx.doi.org/10.2307/2648118

Mwangi, A. M. (1995). The role of urban agriculture for food security in low income areas in Nairobi (Food and Nutrition Studies Programme Report No. 54). Leiden: African Studies Centre. http://hdl.handle.net/1887/479

Narayan, D., \& Pritchett, L.. (1999). Cents and sociability: Household income and social capital in rural Tanzania. Economic Development and Cultural Change, 47(4), 871-897. http://dx.doi.org/10.1086/452436

Ngongo, C. J., Mathingau, F. A., Burke, H., Brieger, W., Frick, K., Chapman, K., \& Breiman, R. (20072008). Community participation to refine measures of socio-economic status in urban slum settings in Kenya. International quarterly of community bealth education, 28(1), 33-49. http://dx.doi.org/10.2190/IQ.28.1.d

Prain, G., Karanja, N., \& Lee-Smith, D. (Eds.). (2010). African urban harvest: Agriculture in the cities of
Cameroon, Kenya and Uganda. Ottowa: International Development Research Centre (IDRC). http://dx.doi.org/10.1007/978-1-4419-6250-8

Putnam, R. D. (2001). Social capital: Measurement and consequences. Isuma Canadian Journal of Policy Research, 2(1), 41-51.

Rakodi, C. (2002). A livelihoods approach: Conceptual issues and definitions. In C. Rakodi \& T. LloydJones (Eds.), Urban livelihoods: A people-centred approach to reducing poverty (pp. 3-22). Sterling, Virginia: Earthscan.

Sampson, R. J., Raudenbush, S. W., \& Earls, F. (1997). Neighborhoods and violent crime: A multilevel study of collective efficacy. Science, 277(5328), 918-924. http://dx.doi.org/10.1126/science.277.5328.918

Schippers, R. R. (2000). African indigenous vegetables: An overview of the cultivated species. Chatham, UK: Natural Resources Institute/ACP-EU Technical Centre for Agricultural and Rural Cooperation.

Scoones, I. (1998). Sustainable rural livelihoods: A framework for analysis (IDS Working Paper 72). Brighton, UK: Institute of Development Studies. Retrieved from https://www.staff.ncl.ac.uk/david. harvey/AEF806/Sconnes1998.pdf

Slater, R. J. (2001). Urban agriculture, gender and empowerment: An alternative view. Development Southern Africa, 18(5), 635-650. http://dx.doi.org/10.1080/03768350120097478

UN-Habitat. (2004, March 17). Dialogue on urban realities (Working paper of the Committee of Permanent Representatives to UN-Habitat for World Urban Forum 2004).

UN-Habitat. (2010). State of the world's cities 2010/2011: Bridging the urban divide. New York: Routledge.

United Nations. (2000). Millenium development goals. Retrieved from http://www.un.org/millenniumgoals/

Villavicencio, L. M. (2009). Urban agriculture as a livelihood strategy in Lima, Peru. In M. Redwood (Ed.), Agriculture in urban planning: Generating livelihoods and food security (pp. 49-72). London: Earthscan and the International Development Research Centre (IDRC).

Waitt, G. (2005). Doing discourse analysis. In I. Hay (Ed.), Qualitative research methods in buman geography (pp. 163-191). New York: Oxford University Press. 
Journal of Agriculture, Food Systems, and Community Development ISSN: 2152-0801 online

www.AgDevJournal.com

WinklerPrins, A. M. G. A., \& de Souza, P. S. (2005). Surviving the city: Urban home gardens and the economy of affection in the Brazilian Amazon. Journal of Latin American Geography 4(1), 107-126. http://dx.doi.org/10.1353/lag.2005.0033
Wratten, E. (1995). Conceptualizing urban poverty. Environment and urbanization, 7(1), 11-38. http://dx.doi.org/10.1177/095624789500700118 